\title{
THE ROLE OF COMPANY REPUTATION IN MITIGATING NEGATIVE WORD OF MOUTH
}

\author{
Shinta RAHMANI ${ }^{1 *}{ }^{*}$, Rizal E. HALIM ${ }^{2}$, Gita GAYATRI ${ }^{3}{ }^{3}$, Asnan FURINTO ${ }^{4}$ \\ 1, 2, ${ }^{3}$ Faculty of Economic and Business, University of Indonesia, Depok, Indonesia \\ ${ }^{4}$ Faculty of Economic and Business, Bina Nusantara University, Jakarta, Indonesia
}

Received 17 June 2020; accepted 4 August 2020

\begin{abstract}
The study aims to investigate whether a company reputation can be used to reduce the impact of negative electronic word of mouth (eWOM). We conducted experimental research in two studies along with 225 college students, who at least have two accounts in different social media, as participants. We use both qualitative and quantitative methodologies. Qualitative research was carried out with focus group interviews to decide the number of high or low negative reviews as well as the level of credibility. Quantitative research used cross-sectional field design by pilot study and the main study. The model was tested and developed using data collected by questionnaires in paper surveys. The results of study 1 suggest that negative eWOM reduces purchase intentions mediated by the subjective norms and perceived behavior control. High negative eWOM reduces purchase intention more than low ones. Study 2 found out that in a condition of high negative eWOM, good company reputation's perception affected purchase intention mediated by attitude. Furthermore, purchase intention is higher when a good company reputation's perception is stronger. Therefor Organizations should convey its company reputation to their customer visually to get a good perception. Further research to investigate another variable that the company has is required.
\end{abstract}

Keywords: company reputation, mitigation, negative electronic word of mouth, purchase intention, theory of planned behavior.

JEL Classification: M30, M31.

\section{Introduction}

Electronic word of mouth (eWOM) is person-to-person communication online or through social media (Yang, 2017). Using eWOM as a source of consumer reference in making decisions has become increasingly important (Hennig-Thurau et al., 2004; Brown et al., 2007; Cheung \& Tadani, 2012; Xiaorong et al., 2011).

Several studies have shown that eWOM has a great deal of influence on consumers' purchase decisions (Xiaorong et al., 2011; Yang, 2017; Thomas et al., 2019), and consumer attitudes (Hsu et al., 2013). An information search is one stage in the process of making a purchase decision (Engel et al., 1968; Kotler \& Keller, 2012). Therefore, information is an important thing that consumers need before deciding to buy a product or service.

eWOM is not always positive. Research has shown that negative WOM is more influential in purchase decisions, attracts more attention, and reaches more people than positive WOM (Cui et al., 2012; De Carlo et al.,
2007; Lau \& Ng, 2001). Negative WOM is defined as interpersonal communication about products and services that put them in an unfavorable light (Weinberger et al., 1981). Chevalier and Mayzlin (2006) found that negative eWOM (online reviews) affected book sales more than positive eWOM.

For producers, negative eWOM is very detrimental because, even one negative review can be damaging (Zhu \& Zhang, 2010). Negative eWOM has had an impact on customer acquisition (Sharp, 2010), customer retention and loyalty (East et al., 2006). Because of the strong negative impact of eWOM, it is important to know how the influence of negative online reviews on consumers' intention to purchase can be managed. Generally, producers reduce the impact of negative online reviews by offering an apology or giving an explanation (Bhandari \& Rodgers, 2018), and responses to customer complaints online (Spark \& Bradley, 2017; Herhausen et al., 2019).

This study examined how company reputation could mitigate the impacts of negative eWOM. Company

*Corresponding author. E-mail: shinta.rahmani@mercubuana.ac.id 
reputation is a variable that the company already has; it is an intangible asset that can be managed by the company. It is rare to find research using company reputation in context of mitigating the impact of negative eWOM.

The second contribution of this research is to propose a strategy to address negative events using the asset of a good company reputation before negative events occur.

\section{Theoritical background and hypotheses}

\subsection{Theory of planned behavior}

As one of the most widely used theories, theory of planned behavior (TPB) was formulated and intended to predict, and change human social behavior. According to TPB (Ajzen, 1991), individuals' behavioral intentions are jointly influenced by three factors: attitude, subjective norms, and perceived behavioral control. TPB has been relied upon as the best model for predicting intentions (Yadav \& Pathak, 2016). The theory of planned behavior is applied in a wide range of contexts, like recalling damaged products on the market (Lin et al., 2011), and food products that contain additives in Taiwan (Chen, 2017). Research in consumer buying behavior after food safety accidents by Mazzocchi et al. (2008) found that attitudes towards behavior, subjective norms and perceived behavior control affected the changes in consumer buying behavior after a food safety accident. Lu et al. (2010) reported that the inclusion of attention to news and perceived credibility of information constructs can enable a higher model fit than that of the original TPB model. This research will apply TPB with negative eWOM as a source of information.

\subsection{Negative word of mouth}

Bachleda and Berrada-Fathi (2016) showed that negative eWOM played an important role in service consumption decisions. Companies must actively manage this form of negative eWOM because studies have shown that the effect of negative eWOM on consumer attitudes towards service providers and purchase intentions is far greater than the effect of positive eWOM (Kudeshia \& Kumar, 2017; DeCarlo et al., 2007). Armelini and Vilanueva Galobart (2011) observed that negative WOM can damage brand reputation and sales. That the quantity of negative reporting will affect negative attitudes is known from the research of Bachleda and Berrada-Fathi (2016). The higher the number of negative testimonials received from each eWOM source, the higher the negative attitude towards the service provider

Taylor and Todd (1995) defined attitudes as "positive or negative feelings of individuals towards the target behavior" (p. 149). Comparing the impact of positive and negative reviews on hotel customer choices, Vermeulen and Seegers (2009) emphasized that such negative reviews resulted in changes in negative attitudes, while positive reviews improved the attitudes of customers towards the hotel. Lee and Cranage (2014) found that negative eWOM influenced attitudes toward restaurants more than positive eWOM. This leads to the first hypothesis of this study:

$\mathrm{H} 1$ : The attitudes of consumers who received high negative eWOM will be less positive than the attitudes of consumers who received low negative eWOM.

According to the theory of planned behavior (TPB), subjective norms are defined as perceived social pressure to perform or not perform behavior by individuals (Ajzen, 1991). Subjective norms are the implementation of personal behavior in accordance with relationships with others who are considered important. These norms also refer to individual pressure when people are expected to take certain actions (Ajzen \& Fishbein, 1977). Subjective norms, such as word-of-mouth recommendations, influence one's attitudes and behavior (Cheung \& Lee, 2008).

Guoqing et al. (2009) examined negative WOM by mediating subjective norms on brand switching. They found that negative WOM had a direct effect on subjective norms and led to brand switching by consumers. In simple terms, it can be concluded that negative eWOM makes subjective norms smaller, meaning that the orientation of other people's views is small and their attitude towards the brand also becomes small/down, which results in being moved to another brand. Thus, it is hypothesized that:

$\mathrm{H} 2$ : Subjective norms of consumers who received high negative eWOM will be less positive than subjective norms who received low negative eWOM.

Perceived behavioral control (PBC) is a measure of the extent to which individuals believe that displaying certain behaviors will be easy or difficult (Hogg \& Vaughan, 2005). PBC is an individual's perception of the ease or difficulty of behavior and the level of control to implement that behavior (Ajzen, 1991). Therefore, if a person has the opportunity and the ability to act according to information he or she believes, then he or she will be motivated to take action.

EWOM negatively influences decision making and hinders purchase (Chen \& Lurie, 2013). Cui et al. (2012) found that positive WOM improved the quality and attitude of consumers toward products and negative WOM reduced them. Jalilvand and Samiei (2012) found that eWOM affected PBC. An individual's attention to negative news and the credibility of the news received by consumers determined the perception of risk about using the product being reported. Thus, the PBC of consumers is affected by negative reviews. Purchase behavior in the TPB framework has a mediator's attitude, subjective norms, and PBC. If eWOM is negative with mediator attitudes, subjective norms, and PBC and results in negative behavior, such as not buying a product, then the three mediators following the negative eWOM become negative. Thus, it can be hypothesized that: 
$\mathrm{H} 3$ : The $\mathrm{PBC}$ of consumers who received high negative eWOM will be smaller than $\mathrm{PBC}$ who received low negative eWOM.

The eWOM phenomenon has changed people's behaviors and decisions, such that they rely more on the opinions of others and the information that they get from others. Consumers even make offline decisions based on information obtained online (Lee et al., 2008). Besides influencing results on sales figures at the corporate level, for example, eWOM also influences individual end-user in terms of their attitudes, trust, or purchase intentions (Doh \& Hwang, 2009; Sparks \& Browning, 2011). Wu and Wang (2011) conducted a study in Taiwan of the effects of eWOM on the purchase of Notebooks, products with high levels of involvement, and shampoos, daily consumption products with low involvement. They found that eWOM positively influenced the purchase intentions of both products.

Negative opinions get more consideration by recipients than positive opinions (Sparks \& Browning, 2011) because negative opinions are considered to be more credible and easily generalized than positive opinions (Chatterjee, 2001). Bachleda and Berrada-Fathi (2016) found that negative eWOM, as well as negative WOM, played an important role in the choice of services that have not been used before. Thus, it can be hypothesized that:

H4: The purchase intentions of consumers who received high negative eWOM will be smaller than the purchase intentions of consumers who received low negative eWOM.

\subsection{Company reputation}

Reputation is a collective representation of a company's past actions and can be measured from time to time (Worcester, 2009). A good reputation is an asset that can increase buyers' expectations about what a company offers (Shapiro, 1983), and it reduces uncertainty about the performance of the product or service. The company's reputation is determined by the relative perspective of the individual and is closely related to the consumer's subjective evaluation of the company (Fombrun \& Shanly, 1990). A positive corporate reputation increases consumer purchase intentions, attitudes toward the company and its products, and brand loyalty, so that company products with negative associations do not always receive negative responses from consumers (Brown \& Dacin, 1997). That is, a good reputation serves as a buffer against negative consumer perceptions (Lange et al., 2011). Negative eWOM has a direct influence on attitudes, subjective norms, and PBC. So, when exposed to negative reviews, the three constructs together will be negative (Chen, 2017). A positive company reputation partially or jointly will moderate the negative eWOM relationship and the three TPB constructs. Thus, it can be stated that:

H5a: Under high negative eWOM conditions, the attitudes of consumers toward a company with a good reputation will be greater than the attitude of consumers toward a company with a bad reputation.

H5b: Under high negative eWOM conditions, the subjective norms of consumers toward a company with a good reputation will be greater than the subjective norms of consumers toward a company with a bad reputation.

H5c: Under high negative eWOM conditions, the PBC of consumers toward a company with a good reputation will be greater than the $\mathrm{PBC}$ of consumers toward a company with a bad reputation.

A company's reputation is defined as the accumulation of opinions, perceptions, and attitudes of consumers towards the company (Fombrun et al., 2000; Fombrun \& Shanly, 1990). Reputation illustrates the ability of organizations to provide value for all stakeholders (Fombrun \& Rindova, 2001). Company reputation significantly influences satisfaction, purchase intention, and company performance (Spreng \& Page, 2001).

In a competitive market, consumers pay attention to information about the company behind the product and brand (Kitchen \& Laurence, 2003). Consumers seek more information when facing a higher risk (Gemunden, 1985), as well as when getting negative eWOM information about the product to be purchased. As stated by Brown and Dacin (1997) and Saxton (1998), a positive company reputation increases consumer purchases, attitudes toward the company, and customer loyalty to the brand. Therefore, it can be stated that:

H6: Under high negative eWOM conditions, the purchase intention of consumers with good company reputation will be greater than purchase intention with bad company reputation.

We conducted two studies to investigate how company reputation serves as a buffer against negative perceptions and mitigates the effect of negative eWOM. In Study 1 we varied the quantity of negative eWOM in a controlled field experiment. We examined whether the high quantity of negative eWOM about a product decreased the intention to buy that product more than a low quantity. Study 1 also examined whether the effect of eWOM was mediated by TPB. In Study 2, a laboratory experiment, we manipulated a company reputation using TV news videos that made announcements about the company to know whether participants' perception would influence purchase intention.

\section{Study 1}

Study 1 was conducted to examine the intention to purchase products that have been exposed to low and high negative eWOM (H4). The products were also used by a control group that was not exposed to negative eWOM. Besides that, the study tested the variables of attitude, subjective norms, and perceived behavior control (H1) (H2), and (H3). 


\subsection{Method}

\subsubsection{Design and participants}

Study 1 involved three treatments on participants (negative eWOM: Low vs high) and non-eWOM negative. The participants were 135 undergraduate students (53 male and 82 female, $M_{\text {age }}=22.05$ ) from Mercu Buana University and Indonesia Banking School. Participants were randomly assigned to follow one of the three treatments.

\subsubsection{Stimulus development}

To create a stimulus, we conducted four pilot studies, each carried out by $30-50$ different Mercu Buana University undergraduate students. Pilot study 1 was an exploratory study to determine which utilitarian products - in this case, beverage products - would be used in the rest of this study. Participants were asked to write down the types of drinks that they commonly purchased because they saw their benefits. The highest-ranking choice was UHT milk products. To control the effect of attitudes on existing brands, Pilot study 2 was conducted to determine fictitious brands. Participants were asked to propose a brand name for UHT milk that had not been used before. From this, we made a list of the five fictitious brands with the most support. Next, a different group of students chose one name from the list. Most chose the name Moo as the brand of the fictitious UHT milk products. Pilot study 3 was conducted to determine what negative reviews influenced participants not to buy UHT milk, and Pilot study 4 was conducted to equate participants' perceptions of high and low negative reviews through interviews with 30 students. These participants provided written answers to a series of questions to find out how many negative reviews were considered low and high, what social media were generally owned by participants, and what parties who submitted online reviews were considered credible.
Based on the results of the pilot studies, packaging images and video advertisements were made to describe Moo milk. Moo milk was presented as having calcium for bone health. Furthermore, a high-fidelity mock-up was made on a smartphone application to access negative reviews on social media Facebook, Twitter, and Instagram (Figure 1). There were three reviews that were somewhat negative and 15 that were highly negative reviews. These reviews were commented on by nutritionists and responded to by the Food and Drug Monitoring Agency (BPOM) as an official institution for controlling food quality in circulation. $\mathrm{BPOM}$ and the nutritionists - seen as credible and trusted sources by the pilot study participants - comprised official institutions (100\%), experts (47\%), and friends or family $(38 \%)$. All these negative reviews were fictitious and were used only for this experimental study.

\subsection{Measurement of the dependent variable}

Participants were asked to respond to a series of statements throughout using a six-point Likert scale. Four statements, adapted from Taylor and Todd (1995) were used to measure attitudes $(\alpha=0.916)$ : (1) Overall, buying Moo milk is a good thing; (2) Generally, buying Moo milk is recommended; (3) Generally, buying Moo milk is safe; (4) Moo milk will give me benefits. Four statements, adapted from Fizben and Ajzen (1975), were used to measure subjective norms ( $\alpha=0.793)$ : (1) Parents suggested I should not buy Moo milk (2) My family members suggested buying Moo milk based on their exp erience (3) My friends suggest I should not buy Moo milk (4) My colleague gives a reference to buy Moo milk. Three statements, adapted from Chen (2017) and Taylor and Todd (1995), were used to measure behavioral control $(\alpha=0.844)$ : (1) I believe I can buy Moo milk (2) I tend to buy Moo milk, (3) I believe that I have the opportunity to buy Moo milk. Five statements, adapted from Taylor and Todd (1995), were used
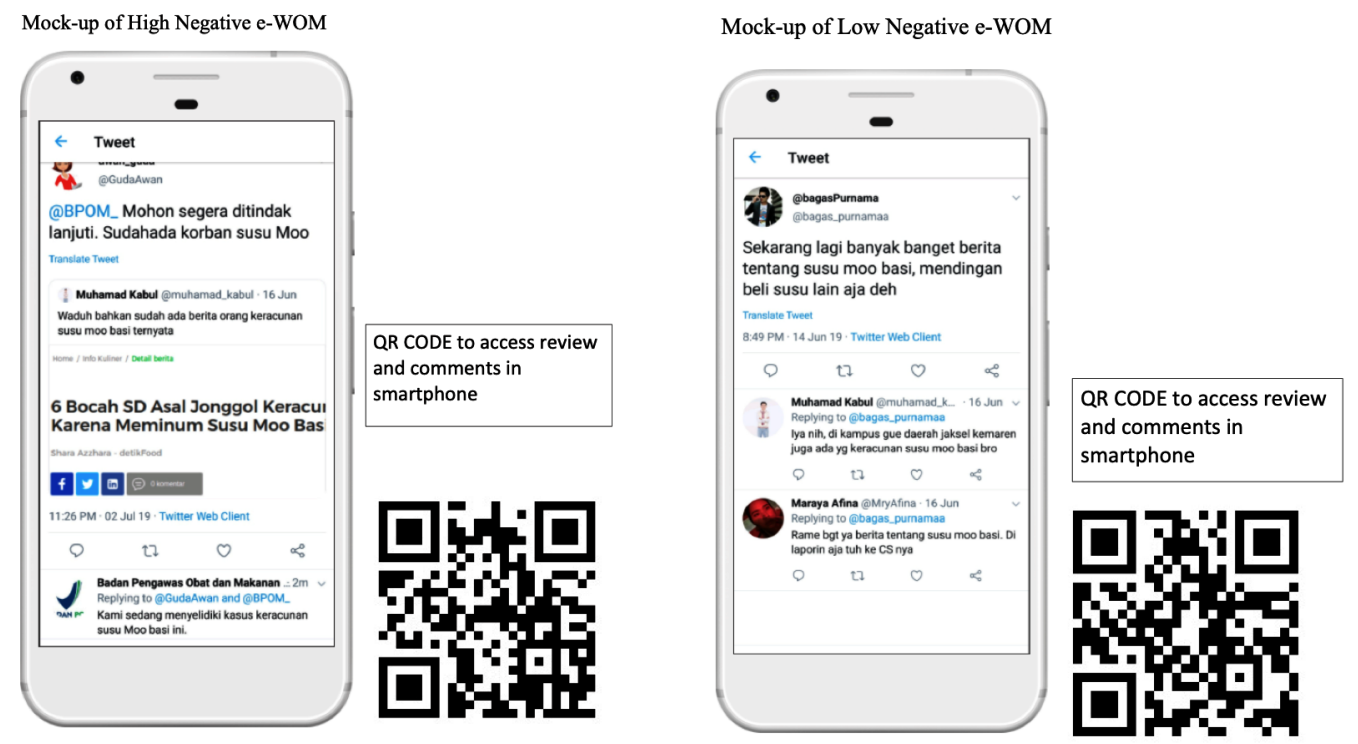

Figure 1. High-fidelity mock-ups of High negative eWOM and Low negative eWOM (source: created for this research, 2019) 
to measure purchase intentions ( $\alpha=0.884)$ : (1) I will look for information to buy Moo milk (2) I plan to buy Moo milk (3) In the next three months I will buy Moo milk (4) Overall, buying Moo milk is not problematic or safe, (5) I will buy Moo milk with my family. All measurements in study 1 had valid instruments with loading factor $>0.6$.

\subsection{Results}

\subsubsection{Manipulation checks}

To find out whether negative eWOM reduced attitudes, subjective norms, $\mathrm{PBC}$, and purchase intentions, participants used a smartphone application to access mock-up shows that gave negative online eWOM about products. In the high negative eWOM conditions, 15 negative eWOM impressions were given, while the low negative eWOM conditions were given two impressions. To measure whether participants felt they received high or low negative eWOM, they were asked to respond to two statements $(\alpha=.981)$ : "The number of negative reviews is large, more than 5 reviews", "The number of negative comments online is small, less than 3 reviews". In the control group, no negative eWOM impressions were given. The results of measurements using the $\mathrm{t}$-test showed that there were significant differences between the high and low eWOM groups $[\mathrm{F}(1,88)=1.456, \mathrm{p}=.000(2$-tailed $)]$. Negative eWOM weakens consumer attitudes towards dairy products. It is estimated that there are consumers' concerns that when products are given massive negative reviews, those reviews are indeed true - that the products are negative - compared to low negative eWOM conditions. This hypothesis was tested using one-way ANOVA with a contrast test. The control group was compared first with the treatment group then with the low and high treatment groups.

\subsubsection{Attitudes}

Attitudes towards the product were measured using four statements. Based on factor analysis, the four statements formed one variable and each had a loading factor $>0.6$ with Cronbach $\alpha=0.916$. The test results using one-way ANOVA using the four questions on the attitude variable showed a significant difference in the high negative eWOM condition group, the low negative eWOM condition, and the control group $[\mathrm{F}(2,132)=146.375, \mathrm{p}=.000]$. The contrast test showed that the control group was significantly higher than the low negative eWOM group $\left(\mathrm{M}_{\text {non-newom }}=\right.$ $\left.17.80, \mathrm{M}_{\text {low }}=15.84, \mathrm{t}=-9.519, \mathrm{p}=.000\right)$, and the low negative eWOM condition group was significantly higher than the negative eWOM group high $\left(\mathrm{M}_{\mathrm{low}}=15.84\right.$, $\left.\mathrm{M}_{\text {high }}=8.51, \mathrm{t}=12.669, \mathrm{p}=.000\right)$ This result supports H1.

\subsubsection{Subjective norms}

Questions to measure subjective norms are four, questions adapted from Fizben and Ajzen (1975). Factor analysis of the four questions formed one variable, and each had a loading factor $>0.6$ with Cronbach $\alpha=0.793$.
Test results using one-way ANOVA using the questions on the subjective norms variable showed a significant difference in the high negative eWOM condition group, the low negative eWOM condition and the control group $[\mathrm{F}(2.132)=127.174, \mathrm{p}=.000]$. The contrast test showed that the control group was not significantly higher than the low negative eWOM group $\left(\mathrm{M}_{\text {non-newom }}=16.82\right.$, $\left.\mathrm{M}_{\text {newom }}=15.84, \mathrm{t}=-9.519, \mathrm{p}=.067\right)$, however the low negative eWOM condition group was significantly higher than the group eWOM negative is high $\left(\mathrm{M}_{\text {low }}=15.84\right.$, $\mathrm{M}_{\text {high }}=9.07, \mathrm{t}=-14.642, \mathrm{p}=.000$ ).

The results of the contrast test showed that the subjective norms of consumers with high negative eWOM was smaller than the subjective norms of consumers with low negative eWOM. This supported $\mathrm{H} 2$.

\subsection{4. $\mathrm{PBC}$}

Perceived behavioral control (PBC) was measured using three question items. Based on the factor analysis, the three questions form one variable and each had a loading factor $>0.6$ with Cronbach $\alpha=0.843$. One-way ANOVA test results on the variable, perceived behavioral control, showed a significant difference between the three groups $(\mathrm{F}(2.132)=$ 81.403, $\mathrm{p}=.000)$. The contrast test found $\left(\mathrm{M}_{\text {low }}=12.24\right.$, $\left.\mathrm{M}_{\text {high }}=7.84, \mathrm{t}=8.982, \mathrm{p}=.000\right)$. It is proven that $\mathrm{PBC}$ consumers who received high negative eWOM will be less positive compared to $\mathrm{PBC}$ consumers who received low negative eWOM. This result supports $\mathrm{H} 3$.

\subsubsection{Purchase intention}

Negative eWOM makes consumer purchase intentions for dairy products decrease. It is estimated that there are consumers' concerns that when a product gets massive negative reviews it indicates that the product is negative. compared to the low negative eWOM condition. This hypothesis was tested using one-way ANOVA with a contrast test. The control group was compared with the treatment group then compared with the low and high treatment groups.

The five statements to test purchase intention formed a variable with a loading factor $>0.6$ and Cronbach $\alpha=$ 0.884. One-way ANOVA test results on the purchase intention variable showed a significant difference between the three groups $(\mathrm{F}(2.132)=93.212, \mathrm{p}=.000)$. A Dunnet-test $(<$ control) showed that participants in the low negative eWOM group were lower than the control group $\left(\mathrm{M}_{\text {low }}=19.49, \mathrm{M}_{\text {non-newom }}=22.16, \mathrm{SE}=0.791\right.$, $\mathrm{p}=.000)$, and the high negative eWOM condition group was lower compared to the control group $\left(\mathrm{M}_{\text {high }}=12.97\right.$, $\left.\mathrm{M}_{\text {non-newom }}=22.16 \mathrm{SE}=0.791, \mathrm{p}=.000\right)$. See Figure 2 The contrast test showed that the difference in purchase intentions in the low negative eWOM group was higher than in the high negative eWOM group $(\mathrm{t}=9.774, \mathrm{p}=.000)$ this result supports $\mathrm{H} 4$.

\subsubsection{Mediation}

We conducted a mediation analysis with attitude, subjective norms, and PBC as mediators of the influence of 


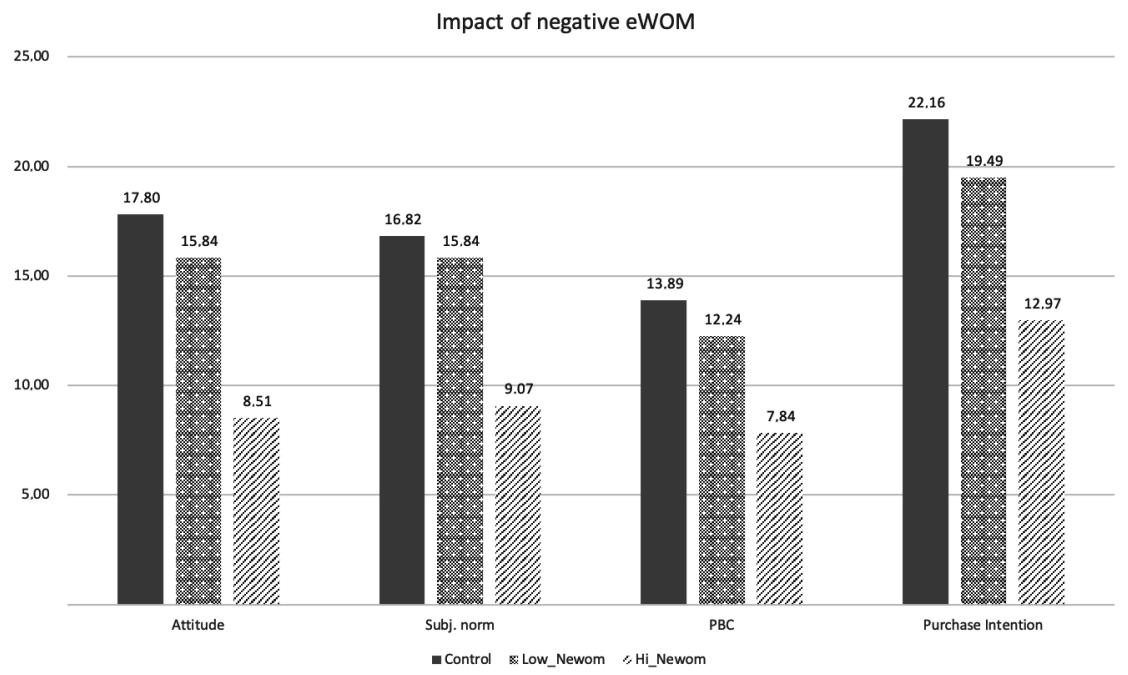

Figure 2. Impact of negative eWOM on attitude, subjective norms, $\mathrm{PBC}$ and purchase intention (source: Rahmani et al., Research data, 2019)

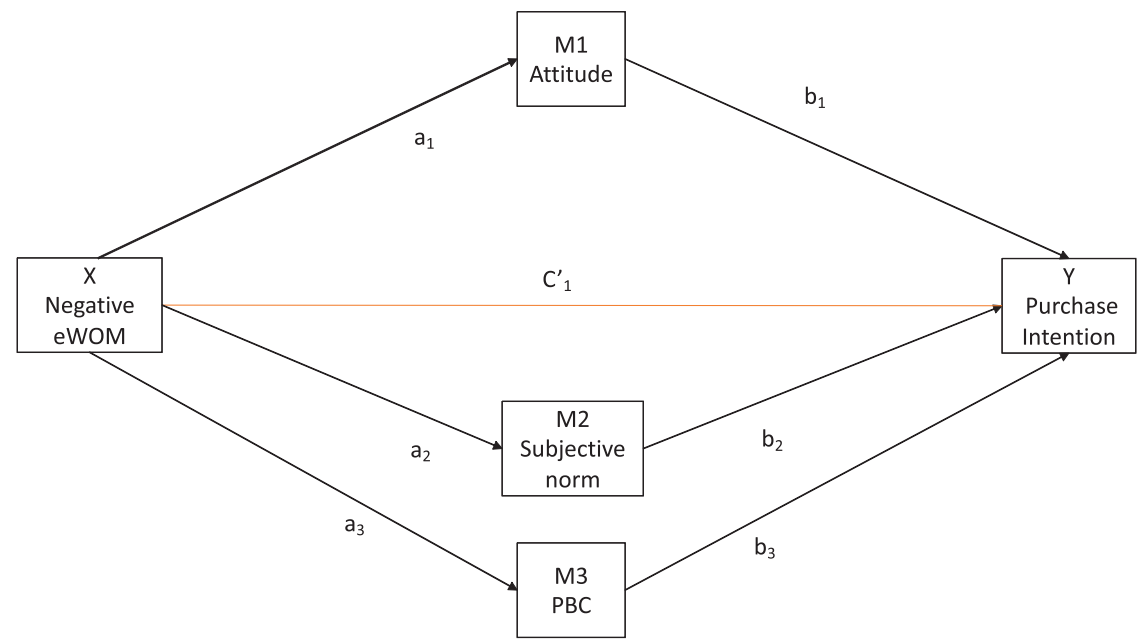

Figure 3. Model framework of study 1

Table 1 . The mediation results of study $1(n=90)$ (source: Research data, 2019)

\begin{tabular}{|c|c|c|c|c|c|c|c|c|c|c|c|c|}
\hline & \multicolumn{12}{|c|}{ Consequent } \\
\hline & & \multicolumn{2}{|c|}{ M1 } & & \multicolumn{2}{|c|}{ M2 } & & \multicolumn{2}{|c|}{ M3 } & & \multicolumn{2}{|c|}{$\mathrm{Y}$} \\
\hline & & Coeff. & & & Coeff & & & Coeff. & & & Coeff. & \\
\hline Antecedent & & SE & $\mathrm{p}$ & & SE & $\mathrm{p}$ & & SE & $\mathrm{p}$ & & SE & $\mathrm{p}$ \\
\hline \multirow{2}{*}{ X (HNwom) } & al & 0.331 & & a2 & -0.303 & & a3 & -0.206 & & $c^{\prime}$ & -0.007 & \\
\hline & & 0.034 & $0.000^{\star *}$ & & 0.034 & $0.000^{* *}$ & & 0.028 & $0.000^{* *}$ & & 0.058 & 0.905 \\
\hline \multirow{2}{*}{ M1 (Attitude) } & & & & & & & & & & b1 & 0.232 & \\
\hline & & & & & & & & & & & 0.153 & 0.132 \\
\hline \multirow{2}{*}{ M2 (Subj. norm) } & & & & & & & & & & b2 & 0.569 & \\
\hline & & & & & & & & & & & 0.148 & $0.000^{*}$ \\
\hline \multirow{2}{*}{ M3 (PBC) } & & & & & & & & & & b3 & 0.378 & \\
\hline & & & & & & & & & & & 0.160 & $0.021^{*}$ \\
\hline \multirow{2}{*}{ Constant } & $\mathrm{i}_{\mathrm{M} 1}$ & 21.044 & & $\mathrm{i}_{\mathrm{M} 2}$ & 20.596 & & $\mathrm{i}_{\mathrm{M} 3}$ & 15.592 & & iy & 2.108 & \\
\hline & & 0.961 & $0.000^{\star *}$ & & 0.959 & $0.000^{* *}$ & & 0.802 & $0.000^{* *}$ & & 3.178 & 0.509 \\
\hline
\end{tabular}

Note: Bootstrap $=1000,{ }^{*}<0.05,{ }^{* *}<0.001$. 
negative eWOM on purchase intentions (See Figure 3) using PROCESS SPSS Macro model 4 and bootstrap analysis (Hayes, 2018). We tested mediation in groups that received negative eWOM treatment on attitude, subjective norms, and perceived behavior control $(\mathrm{PBC})$ $(\mathrm{a} 1=-0.332, \mathrm{t}=-9.878, \mathrm{p}<.05, \mathrm{a} 2=-0.303, \mathrm{t}=-9.028$, $\mathrm{p}<.05$, a3 $=-0.206, \mathrm{t}=-7.362, \mathrm{p}<.05)$ and the effect of attitude on purchase intention $(\mathrm{b} 1=0.232, \mathrm{t}=$ $1.520, p>0.05$ is not significant), while the influence of subjective norms and perceived behavior control on purchase intention $(\mathrm{b} 2=0.569, \mathrm{t}=3.854, \mathrm{p}<.05 ; \mathrm{b} 3=$ $0.378, \mathrm{t}=2.361, \mathrm{p}<.05)$. Both were significant. The direct effect of negative eWOM on purchase intention ( $c=-0.007, t=-0.120, p>.05)$ was not significant. See Table 1 This indicated full mediation (Zhao et al., 2010; Baron \& Kenny, 1986).

\section{Study 2}

Study 2 was a replication of Study 1 with a company reputation, as a moderator. Moreover, Study 2 was tests whether a company's reputation can reduce the impact of negative eWOM on attitudes, subjective norms, $\mathrm{PBC}$, and purchase intentions (H5a, H5b, H5c, and H6).

To that end, we manipulated the company's reputation in two ways, namely good and bad company reputation, all of which were applied to the high negative eWOM conditions. This is based on the results of study 1 , in which for high negative eWOM conditions, purchase intention was the lowest compared to the low negative eWOM conditions or no exposure to negative reviews in the control group.

\subsection{Method}

\subsubsection{Design and participants}

Study 2 had two treatment conditions (company reputation: good vs bad) between design participants. The participants in this study were 90 undergraduate students of Mercu Buana University (26 male, 64 females; $\mathrm{M}_{\text {age }}=$ 22.26) who were randomly assigned to one of two conditions.

\subsubsection{Stimulus development}

Two types of TV news videos about a company that produces Moo milk were made for this research. One video presented coverage of reputable companies, and the other video presented coverage of companies with bad reputations. The videos had the same picture at the beginning, meaning that the two treatment groups got the same information about the company. In the video about the company with a good reputation, they were paying attention to employee welfare. They also had a company social responsibility (CSR) programs, and fostered cattle farmers. However, the video about the company with a bad reputation included strike of fostered farmers and company employees who were dissatisfied with payment. Both videos had the same storyline but in different versions.

\subsubsection{Procedure}

Study 2 aimed to identify the factors that can mitigate the impact of negative eWOM. Company reputation was the factor used in this study as a moderator that was expected to mitigate negative impacts. The 90 participants were randomly assigned to two different classrooms. All participants were shown the advertisement video for Moo milk twice. Then they were asked to read negative eWOM on smartphones accessed by using the QR code provided on the distributed paper. For easy access to negative reviews, participants were also given a paper containing screenshots of eWOM negative impressions. After reading negative reviews, participants answered the high negative eWOM questions then were shown one of the TV news videos according to the conditions. Furthermore, they answered research questions, filled out demographic forms, and answered manipulation checks.

\subsection{Results}

\subsubsection{Manipulation checks}

Three statements were used to measure the company's reputation: (1) The company conducts activities that benefit the community and the environment, (2) the company acts according to ethics and obeys the law, and (3) the company's reputation is good $(\alpha=0.827)$. All these statements had a loading factor $>0.6$. The $\mathrm{t}$-test showed that there were significant differences between the groups of good and bad company reputation $\left(\mathrm{M}_{\mathrm{good}}=12.80, \mathrm{SD}=\right.$ $2.865 ; \mathrm{M}_{\text {bad }}=7.69, \mathrm{SD}=3.267-7,890 ;[\mathrm{F}(1,88)=1.682$, $\mathrm{p}=.000])$. This finding means that the manipulation was going well.

\subsubsection{Attitude, subjective norms, $P B C$}

Study 1 showed that negative eWOM decreases attitudes, subjective norms, and behavior control. Study 2 examined the variable of a company's reputation as a factor that mitigated negative eWOM. In this section, we examine whether attitudes, subjective norms, and behavior control in the group of good reputation conditions were higher than in the group of bad reputation conditions in high negative eWOM.

The results of the t-test showed a significant difference in attitude between the group of good company reputation conditions and the group of bad company reputation conditions at high negative eWOM $\left(\mathrm{M}_{\text {good }}=14.91, \mathrm{SD}=\right.$ 2.548; $\mathrm{M}_{\text {bad }}=9.29, \mathrm{SD}=2.849 ;[\mathrm{F}(1.88)=0.039, \mathrm{p}=$ $.000])$. These result support $\mathrm{H} 5 \mathrm{a}$.

The subjective norms variable in the group condition of good company reputation was higher than in the group of bad reputation condition in high negative eWOM $\left(\mathrm{M}_{\mathrm{good}}=14.62, \mathrm{SD}=2.733 ; \mathrm{M}_{\mathrm{bad}}=9.84, \mathrm{SD}=\right.$ 2.946; $[\mathrm{F}(1.88)=0.72, \mathrm{p}=.000])$ Thus, H5b is supported.

Likewise, the perceived behavior control variable in the good company reputation condition group was higher than in the bad reputation condition group in the high negative $\mathrm{eWOM}\left(\mathrm{M}_{\mathrm{good}}=11.02, \mathrm{SD}=2.580 ; \mathrm{M}_{\mathrm{bad}}=8.33\right.$, 
$\mathrm{SD}=3.411 ;[\mathrm{F}(1.88)=2.943, \mathrm{p}=.000]$. Thus, $\mathrm{H} 5 \mathrm{c}$ is proven.

The t-test on the intention to purchase variables in the group condition of good company reputation was higher than in the group of bad reputation conditions in high negative eWOM $\left(\mathrm{M}_{\text {good }}=21.02, \mathrm{SD}=2.896 ; \mathrm{M}_{\text {bad }}=\right.$ 13.22, $\mathrm{SD}=3.617 ;[\mathrm{F}(1.88)=0.72, \mathrm{p}=.000])$. These support H6.

\subsubsection{Moderated mediation}

The main goals of the moderated by company reputation was to mitigate the decline of purchase intention cause by negative eWOM. We tested moderated mediation in relationship of high negative eWOM to attitude, subjective norms, perceived behaviour control and purchase intention using PROCESS SPSS Macro model 8 and bootstrap analysis (Hayes, 2018).

Table 2. The moderated mediation results of Study $2(n=90)$ (source: Rahmani et al., Research Data, 2019)

\begin{tabular}{|c|c|c|c|c|c|c|c|c|c|c|c|c|}
\hline & & \multicolumn{11}{|c|}{ Consequent } \\
\hline & \multicolumn{3}{|c|}{ M1 (Attitude) } & \multicolumn{3}{|c|}{ M2 (Subj.norm) } & \multicolumn{3}{|c|}{ M3 (PBC) } & \multicolumn{3}{|c|}{ Y (Purchase int) } \\
\hline & & Coeff. & SE & & Coeff. & SE & & Coeff. & SE & & Coeff. & SE \\
\hline Antecedent & & $\mathrm{CI}$ & $\mathrm{p}$ & & $\mathrm{CI}$ & $\mathrm{p}$ & & $\mathrm{CI}$ & $\mathrm{p}$ & & $\mathrm{CI}$ & $\mathrm{p}$ \\
\hline \multirow{2}{*}{$\begin{array}{l}\text { X } \\
\text { (CoRep) }\end{array}$} & a1 & -23.621 & 11.868 & $\mathrm{a} 2$ & -18.848 & 10.654 & a3 & -27.036 & 11.064 & c'1 & -11.680 & 11.764 \\
\hline & & & $0.050^{*}$ & & & 0.080 & & & $0.017^{\star}$ & & & 0.324 \\
\hline \multirow{2}{*}{$\begin{array}{l}\text { M1 } \\
\text { (Attitude) }\end{array}$} & & - & & & - & & & - & & b1 & 0.509 & 0.125 \\
\hline & & & & & & & & & & & & $0.000^{* *}$ \\
\hline \multirow{2}{*}{$\begin{array}{l}\text { M2 } \\
\text { (Subj. norm) }\end{array}$} & & - & & & - & & & - & & b2 & 0.481 & 0.129 \\
\hline & & & & & & & & & & & & $0.000^{* *}$ \\
\hline \multirow{2}{*}{$\begin{array}{l}\text { M3 } \\
(\mathrm{PBC})\end{array}$} & & - & & & - & & & - & & b3 & 0.114 & 0.131 \\
\hline & & & & & & & & & & & & 0.386 \\
\hline \multirow{2}{*}{$\begin{array}{l}\text { W } \\
\text { (Corep) }\end{array}$} & d1 & -39.21 & 18.928 & $\mathrm{~d} 2$ & -30.250 & 16.991 & $\mathrm{~d} 3$ & -44.724 & 17.645 & $\mathrm{~d} 4$ & -21.506 & 18.810 \\
\hline & & & $0.041^{\star}$ & & & 0.079 & & & $0.013^{*}$ & & & 0.256 \\
\hline \multirow{2}{*}{$\mathrm{X} \times \mathrm{W}$} & ald1 & 0.823 & 0.394 & $\mathrm{a} 2 \mathrm{~d} 2$ & 0.638 & 0.354 & a3d3 & 0.935 & 0.368 & c'1d4 & 0.451 & 0.392 \\
\hline & & {$[.039,1.607]$} & $0.040^{*}$ & & {$[.066,1.342]$} & 0.075 & & {$[.204,1.666]$} & $0.013^{*}$ & & {$[-.329,1.231]$} & 0.254 \\
\hline \multirow{3}{*}{ Constant } & $\mathrm{i}_{\mathrm{M} 1}$ & 1136.048 & 569.493 & $\mathrm{i}_{\mathrm{M} 2}$ & 904.682 & 511.225 & $\mathrm{i}_{\mathrm{M} 3}$ & 1302.833 & 530.898 & iy & 561.392 & \\
\hline & & & $0.049^{\star}$ & & & 0,080 & & 530.898 & $0.016^{*}$ & & 564.627 & 0.323 \\
\hline & \multicolumn{3}{|c|}{$\begin{array}{c}\mathrm{R}^{2}=0.264 \\
F(3.86)=10.266 \\
p<0.001\end{array}$} & \multicolumn{3}{|c|}{$\begin{array}{c}\mathrm{R}^{2}=0.140 \\
F(3.86)=4.677 \\
p<0.004\end{array}$} & \multicolumn{3}{|c|}{$\begin{array}{c}\mathrm{R}^{2}=0.140 \\
\mathrm{~F}(3.86)=4.677 \\
\mathrm{p}<0.004\end{array}$} & \multicolumn{3}{|c|}{$\begin{array}{c}\mathrm{R}^{2}=0.639 \\
\mathrm{~F}(3.86)=24.455 \\
\mathrm{p}<0.000\end{array}$} \\
\hline
\end{tabular}

Note: $\left({ }^{*}<0.05,{ }^{* *}<0.01\right)$.

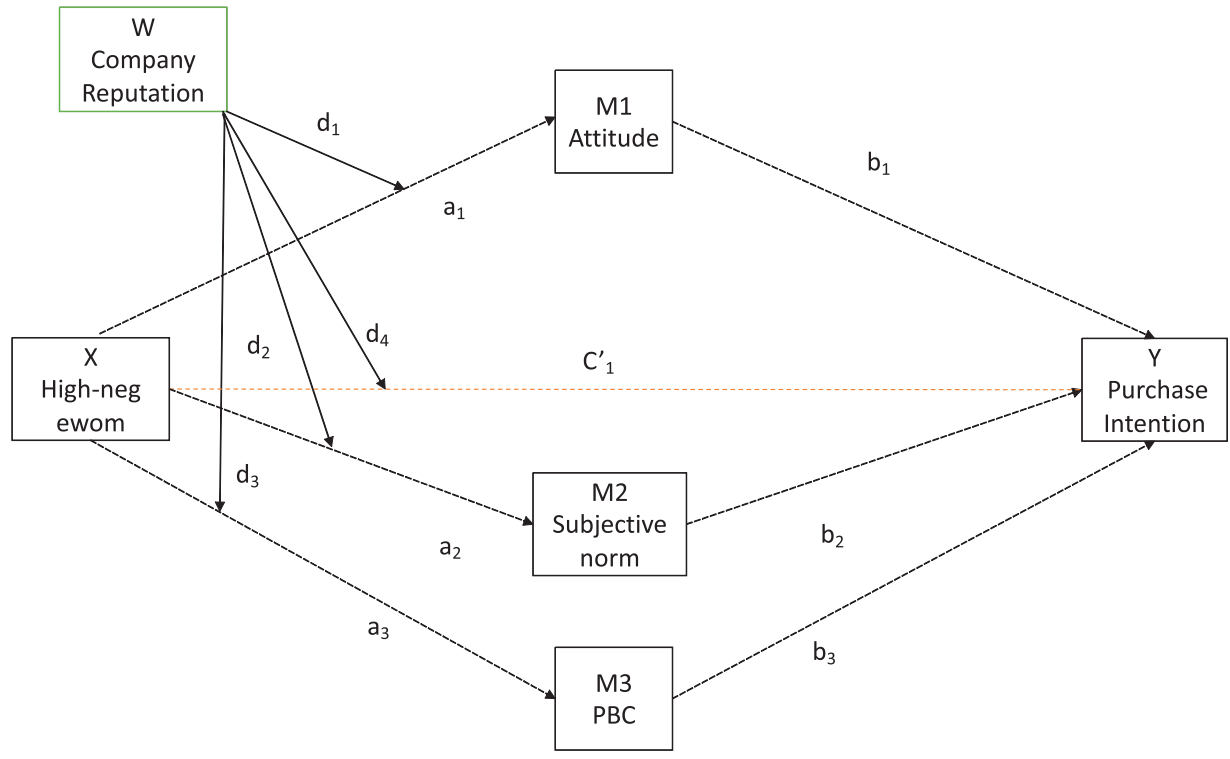

Figure 4. Research model study 2 
In order to test whether differences in good and bad company reputation perception underlie the difference of attitude, subjective norms, $\mathrm{PBC}$ and purchase intention, we conducted moderated mediation analysis. We examine whether different perception of company reputation moderate the a and c' path of our model (Figure 4) with differences in attitude, subjective norms and perceived behavior control mediate the purchase intention. We tested the model with 5,000 bootstrap iteration (Table 2).

The indirect effect through attitude was significant and greater for good company reputation with confidence interval: $-1.131[-2.579,-.355], 1.262[.584,1.974], .3 .656$ $[1.642,5935]$ for company reputation level $25.987,31.700$, 37.413 respectively, corresponding to the mean company reputation and plus or minus one standard deviation from mean. The index of moderated mediation was significant (95\% CI $[.181, .731]$. The indirect effect through subjective norms, perceived behavior control and direct effect was not significant. The direction of the effects in the mediation analysis indicates that the influence of high negative eWOM to attitude was stronger for participants with good company reputation, which in turn contributed to higher purchase intention.

\section{Discussion}

The results of study 1 showed that negative electronic word of mouth had a significant effect in reducing the intention to purchase negatively reviewed products. The higher the negative eWOM, the lower the purchase intention. This is in line with the research of Bachleda and Berrada-Fathi (2016); Lee et al. (2008) because more negative reviews are perceived as negative product.

This research shows that the negative effect of eWOM does not influence purchase intentions directly but through mediators. From the measurement results of this study, attitude does not mediate purchase intentions from the negative eWOM effect, it was mediated by subjective norms and PBC. These results are different from previous research which found that Attitude, as well as a subjective norm and perceived behavior control, affected purchase intention (Mazzocchi, 2008; Chen, 2017). However, the attitude that cannot predict purchase intention also exists in a meta-analysis conducted by Wallace et al. (2005); Sniehotta et al. (2014). Meanwhile, subjective norm mediated purchase intention may be due to the research conducted in a country with low individualistic value (Hofstede, 1993) beside that, participants being college students with an average age of 22 years old, so that the role of friends or group references is indispensable in purchasing decisions (Saputri \& Wandebori, 2014). Because the effect of negative eWOM can spread quickly, it is good if company have any tools to avoid the damage too far.

In study 2, company reputation was used as a moderator to influence purchase intention mediated by attitude, subjective norm, and perceived behavior control. As in study 1 , there was no direct effect affecting purchase intention, but there was indirect effect through attitude. This result prove that a good company reputation becomes a buffer against negative consumer perception (Lange et al., 2011). Products with negative reviews do not always receive negative responses from consumers (Brown \& Dacin, 1997). Attitude is the only significant mediator to increase purchase intention, possibly because the company reputation is determined by the relative perspective of the individual and subjective evaluation of the company (Fombrun \& Shanley, 1990). So that in this perspective the role of the individual is quite large.

In this study, we use the stimulus to manipulate company reputation in the form of video. Company reputation can be obtained by providing information to consumers of what good things the company does in example charity and CSR program or employee outing. The information provided should be online, like social media so that it is easily transmitted and spread quickly. Therefore, good company reputation perspective can be reached. The company needs to have a social media account (Becker \& Lee, 2019) so he can immediately detect if there are any negative reviews about the company circulating. We propose company to be proactive rather than reactive to negative eWOM. So, the impact can be mitigated, before company find another way or choose the best answer to response (Herhausen et al., 2019)

\section{Conclusions}

Negative electronic word of mouth is often occurring, and cause damage. Several studies have been conducted to reduce the negative impact of negative electronic word of mouth and they were mostly focused on improvement efforts after negative events occurred. Because of its rapid spread and difficult to control, mitigation efforts are needed before negative events occur. Therefore, mitigation of negative eWOM before the news spreads will help lessen adverse effects. Interestingly in study 1 , we found that subjective norms had the most significant impact. This might because the participant were college students who were concerned with their peer words.

We found in study 2 that a company's good deeds have a positive impact. We recommend that companies convey their good reputation visually to consumers on regular based so that the company's reputation is perceived well and can be one of the tools to reduce negative perceptions.

The participants were a limitation of this research, we encourage future research to have more diverse participants. Beside company's reputation, there are still other company assets such as product claims and brand loyalty. Future research should explore whether those variables can mitigate negative electronic word of mouth.

\section{Funding}

This work was supported by the University of Indonesia under Grant PITMA 2019-2020. 


\section{Author contributions}

SR, GG and AF conceived the study and were responsible for the design and development of the data analysis. REH and SR were responsible for data collection and analysis. $\mathrm{REH}$ and $\mathrm{AF}$ were responsible for data interpretation. SR wrote the first draft of the article.

\section{Disclosure statement}

The authors declare that there is no conflict of interest.

\section{References}

Armelini, Y. G., \& Villanueva Galobart, J. (2011). Adding social media to the marketing mix, the power of word of mouth. IESE Insight, (9), 29-36. https://doi.org/10.15581/002.ART-1968

Ajzen, I. (1991). The theory of planned behavior. Organizational Behavior and Human Decision Processes, 50(2), 179-211. https://doi.org/10.1016/0749-5978(91)90020-T

Ajzen, I., \& Fishbein, M. (1977). Attitude-behaviour relations: A theoretical analysis and review of empirical research. Psychological Bulletin, 84(5), 888-918. https://doi.org/10.1037/0033-2909.84.5.888

Bachleda, C., \& Berrada-Fathi, B. (2016). Is negative eWOM more influential than negative pWOM? Journal of Service Theory and Practice, 26(1), 109-132. https://doi.org/10.1108/JSTP-11-2014-0254

Baron, R. M., \& Kenny, D. A. (1986). The moderator-mediator variable distinction in social psychological research: Conceptual, strategic and statistical considerations. Journal of Personality and Social Psychology, 51(6), 1173-1182. https://doi.org/10.1037//0022-3514.51.6.1173

Becker, K., \& Lee, J. W. (2019). Organizational usage of social media for corporate reputation management. The Journal of Asian Finance, Economics and Business, 6(1), 231-240. https://doi.org/10.13106/jafeb.2019.vol6.no1.231

Bhandari, M., \& Rodgers, S. (2018). What does the brand say? Effects of brand feedback to negative eWOM on brand trust and purchase intentions. International Journal of Advertising, 37(1), 125-141. https://doi.org/10.1080/02650487.2017.1349030

Brown, J., Broderick, A. J., \& Lee, N. (2007). Word of mouth communication within online communities: Conceptualizing the online social network. Journal of Interactive Mark, 21(3), 2-20. https://doi.org/10.1002/dir.20082

Brown, T. J., \& Dacin, P. A. (1997). The company and the product: corporate associations and consumer product responses. Journal of Marketing, 61(1), 68-84. https://doi.org/10.1002/dir.20082

Chatterjee, P. (2001). Online reviews - do consumers use them?. In M. C. Gilly \& J. Myers-Levy (Eds.), Advances in consumer research. Association for Consumer Research.

Cheung, C. M., \& Lee, M. K. (2008). Online consumer reviews: does negative electronic word-of-mouth hurt more? In Paper presented at Proceedings of the 14th Americas Conference on Information Systems. Toronto, Canada.

Cheung, C., \& Tadani, D. (2012). The impact of electronic wordof-mouth communication: A literature analysis and integrative model. Decision Support Systems, 54, 461-470. https://doi.org/10.1016/j.dss.2012.06.008
Chen, Z., \& Lurie, N. H. (2013). Temporal contiguity and negativity bias in the impact of online word of mouth. Journal of Marketing Research, 50(4), 463-476.

https://doi.org/10.1509/jmr.12.0063

Chen, M. (2017). Modeling an extended theory of planned behavior model to predict intention to take precautions to avoid consuming food with additives. Food Quality and Preference, 58, 24-33. https://doi.org/10.1016/j.foodqual.2017.01.002

Chevalier, J., \& Mayzlin, D. (2006). The effect of word-of-mouth on sales: online book reviews. Journal of Marketing Research, 43(3), 345-354. https://doi.org/10.1509/jmkr.43.3.345

Cui, G., Lui, H., \& Guo, X. (2012). The effect of online consumer reviews on new product sales. International Journal of Electronic Commerce, 17(1), 39-58. https://doi.org/10.2753/JEC1086-4415170102

DeCarlo, T., Laczniak, R., Motley, C., \& Ramaswami, S. (2007). Influence of image and familiarity on consumer response to negative word-of-mouth communication about retail entities. Journal of Marketing Theory and Practice, 15(1), 41-51. https://doi.org/10.2753/MTP1069-6679150103

Doh, S., \& Hwang, J. (2009). How consumers evaluate eWOM (electronic word-of-mouth) messages. Cyber Psychology \& Behavior, 12(2), 193-197. https://doi.org/10.1089/cpb.2008.0109

East, R., Hammond, K., \& Gendall, P. (2006). Fact and fallacy in retention marketing. Journal of Marketing Management, 22(1-2), 5-23. https://doi.org/10.1362/026725706776022245

Engel, J. F., Kollat, D. T., \& Blackwell, R. D. (1968). Consumer behavior. Holt, Rinehart \& Winston.

Fombrun, C., \& Shanley, M. (1990). What's in a name? Reputation building and corporate strategy. Academy of Management Journal, 33(2), 233. https://doi.org/10.5465/256324

Fombrun, C. J., \& Rindova, V. P. (2001). Fanning the flame: Corporate reputations as social constructions of performance. In J. Porac \& M. Ventresca (Eds.), Constructing markets and industries. Oxford University Press.

Fombrun, C., Gardberg, N., \& Sever, J. (2000). The reputation quotient SM: A multi-stakeholder measure of corporate reputation. Journal of Brand Management, 7, 241-255. https://doi.org/10.1057/bm.2000.10

Gemunden, H. G. (1985). Perceived risk and information search. A systematic meta-analysis of the empirical evidence. International Journal of Research in Marketing, 2(2), 79-100. https:// doi.org/10.1016/0167-8116(85)90026-6

Guoqing, G., Zhongke, Z., Kai, C., \& Xiaofan, W. (2009). The influence of WOM on consumers' intention of brand switching: The mediate role of subjective norms. In Proceedings of the Summit International Marketing Science and Management Technology Conference (pp. 48-54). Beijing, China.

Hayes, A. F. (2018). Introduction to mediation, moderation and conditional process analysis: A regression-based approach. The Guilford Press.

Hennig-Thurau, T., Gwinner, K., Walsh, G., \& Gremler, D. (2004). Electronic word-of-mouth via consumer-opinion platforms: what motivates consumers to articulate themselves on the internet?". Journal of Interactive Marketing, 18(1), 38-52. https://doi.org/10.1002/dir.10073

Herhausen, D., Ludwig, S., Grewal, D., Wulf, J., \& Schoegel, M. (2019). Detecting, preventing, and mitigating online firestorms in brand communities. Journal of Marketing, 83(3), 1-21. https://doi.org/10.1177/0022242918822300

Hofstede, G. (1993). Cultural constraints in management theories. The Academy of Management Executive, 7(1), 81-94. https://doi.org/10.5465/ame.1993.9409142061 
Hogg, A. M., \& Vaughan, G. M. (2005). Social psychology ( $4^{\text {th }}$ ed.). Prentice-Hall.

Hsu, C. L., Lin, J. C., \& Chiang, H. S. (2013). The effects of blogger recommendations on customers' online shopping intentions. Internet Research, 23(1), 69-88. https://doi.org/10.1108/10662241311295782

Jalilvand, M., \& Samiei, N. (2012). The impact of electronic word of mouth on a tourism destination choice: testing the theory of planned behavior (TPB). Internet Research, 22(5), 591-612. https://doi.org/10.1108/10662241211271563

Kitchen, P. J., \& Laurence, A. (2003). Industry survey corporate reputation: an eight-country analysis, Corporate Reputation Review, 6(2), 103-117.

https://doi.org/10.1057/palgrave.crr.1540193

Kotler, P., \& Keller, K. L. (2012). Marketing management (Vol. 14). Pearson Education, Prentice Hall.

Kudeshia, C., \& Kumar, A. (2017). Social eWOM: does it affect the brand attitude and purchase intention of brands? Management Research Review, 40(3), 310-330. https://doi.org/10.1108/MRR-07-2015-0161

Lange, D., Lee, P. M., \& Lee, Y. D. (2011). Organizational reputation: A Review, Journal of Management, 37(1), 153-184. https://doi.org/10.1177/0149206310390963

Lau, G. \& Ng, S. (2001). Individual and situational factors influencing negative word-of-mouth behaviour. Canadian Journal of Administrative Sciences, 18(3), 163-178.

https://doi.org/10.1111/j.1936-4490.2001.tb00253.x

Lee, C., \& Cranage, D. (2014). Toward understanding consumer processing of negative online word-of-mouth communication: the roles of opinion consensus and organizational response strategies. Journal of Hospitality \& Tourism Research, 38(3), 330-360. https://doi.org/10.1177/1096348012451455

Lee, J., Park, D. H., \& Han, I. (2008). The effect of negative online consumer reviews on product attitude: An information processing view. Electronic Commerce Research and Applications, 7, 341-352. https://doi.org/10.1016/j.elerap.2007.05.004

Lin, C., Chen, S., Chiu, C., \& Lee, W. (2011). Understanding purchase intention during product-harm crises: moderating effects of perceived corporate ability and corporate social responsibility. Journal of Business Ethics, 102(3), 455-471. https://doi.org/10.1007/s10551-011-0824-y

Lu, H., Hou, H., Dzwo, T., Wu, Y., Andrews, J. E., Weng, S., Lin, M., \& Lu, J. (2010). Factors influencing intentions to take precautions to avoid consuming food containing dairy products: Expanding the theory of planned behaviour. British Food Journal, 112(9), 919-933.

https://doi.org/10.1108/00070701011074318

Mazzocchi, M., Lobb, A., Traill, W.B., \& Cavicchi, A. (2008). Food scares and trust: A European study. Journal of Agricultural Economics, 59(1), 2-24. https://doi.org/10.1111/j.1477-9552.2007.00142.x

Park, D. H., Lee, J., \& Han, I. (2007). The Effect of on-line consumer reviews on consumer purchasing intention: the moderating role of involvement. International Journal of Electronic Commerce, 11(4) (Summer, 2007), 125-148. https://doi.org/10.2753/JEC1086-4415110405

Saxton, M. K. (1998). Where do reputations come from? Corporate Reputation Review, 1(4), 393-399.

https://doi.org/10.1057/palgrave.crr.1540060

Saputri, D. V., \& Wandebori, H. (2014). Consumer socialization: a comparison between Indonesian Third Culture Kids (TCKs) and Non-TKCs. Journal of Business and Management, 3(6), 612-619.
Sharp, B. (2010). How brands grow: What marketers don't know. Oxford University Press. https://doi.org/10.5860/ CHOICE.48-3373

Shapiro, C. (1983). Premiums for high quality products as returns to reputations. The Quarterly Journal of Economics, 98(4) (Nov., 1983), 659-680. https://doi.org/10.2307/1881782

Sniehotta, F. F., Presseau, J., \& Araújo-Soares, V. (2014). Time to retire the theory of planned behaviour. Health Psychology Review, 8(1), 1-7. https://doi.org/10.1080/17437199.2013.869710

Sparks, B. A., \& Bradley, G. (2017). A “Triple A" Typology of responding to negative Consumer-generated online reviews. Journal of Hospitality \& Tourism Research, 41(6), 719-745. https://doi.org/10.1177/1096348014538052

Sparks, B. A., \& Browning, V. (2011). The impact of online reviews on hotel booking intentions and perception of trust. Tourism Management, 32(6), 1310-1323. https://doi.org/10.1016/j.tourman.2010.12.011

Spreng, R. A., \& Page, T. J. (2001). The impact of confidence in expectations on consumer satisfaction, 18(11), 1187-1204. https://doi.org/10.1002/mar.1049

Taylor, S., \& Tood, P. (1995). An integrated model of waste managient behavior: A test of household recycling and composting intentions. Journal Environment and Behavior, 27(5), 603-630. https://doi.org/10.1177/0013916595275001

Thomas, M., Wirtz, B. W., \& Weyerer, J. C. (2019). Determinants of online review credibility and its impact on consumers' purchase intention. Journal of Electronic Commerce Research, 20(1), 1-20. http://www.jecr.org/sites/default/ files/2019vol20no1_Paper1.pdf

Vermeulen, I., \& Seegers, D. (2009). Tried and tested: The impact of online hotel reviews on consumer consideration. Tourism Management, 30, 123-127.

https://doi.org/10.1016/j.tourman.2008.04.008

Weinberger, M., Allen, C., \& William, D. (1981). Negative information: perspectives and research directions. In B. Kent \& A. A. Monroe (Eds.), NA - Advances in Consumer Research, Vol. 08 (pp. 398-4040). Association for Consumer Research.

Wallace, D. S., Paulson, R. M., Lord, C. G., \& Bond Jr, C. F. (2005). Which behaviors do attitudes predict? Meta-analyzing the effects of social pressure and perceived difficulty. Review of General Psychology, 9(3), 214-227.

https://doi.org/10.1037/1089-2680.9.3.214

Worcester, S. R. (2009). Reflections on corporate reputations. Management Decision, 47(4), 573-589.

https://doi.org/10.1108/00251740910959422

Wu, P. C., \& Wang, D. (2011). The influences of electronic wordof-mouth message appeal and message source credibility on brand attitude. Asia Pacific Journal of Marketing and Logistics, 23(4), 448-472. https://doi.org/10.1108/13555851111165020

Xiaorong, F., Bin, Z., Qinghong, X., Liuli, X., \& Yu, C. (2011). Impact of quantity and timeliness of EWOM information on consumer's online purchase intention under C2C environment. Asian Journal of Business Research, 1(2). https://doi.org/10.14707/ajbr.110010

Yadav, R., \& Pathak, G. S. (2016) Young consumers' intention towards buying green products in a developing nation: Extending the theory of planned behaviour. Journal of Cleaner Production, 135(2016), 732e739.

https://doi.org/10.1016/j.jclepro.2016.06.120

Yang, F. X. (2017). Effects of restaurant satisfaction and knowledge sharing motivation on ewom intentions: the moderating 
role of technology acceptance factors. Journal of Hospitality \& Tourism Research, 41(1), 93-127.

https://doi.org/10.1177/1096348013515918

Zhao, X., Lynch, J. G., \& Qimei, C. (2010). Reconsidering Baron and Kenny: myths and truths about mediation analysis. Journal of Consumer Research, 37(2), 197-206. https://doi.org/10.1086/651257

Zhu, F., \& Zhang, X. (2010). Impact of online consumer reviews on sales: the moderating role of product and consumer characteristics. Journal of Marketing, 74(2), 133-148.

https://doi.org/10.1509/jmkg.74.2.133 